\title{
Relative potential of rhizobium species to enhance the growth and yield attributes of cotton (Gossypium hirsutum L.)
}

\section{Amjad Qureshi a,*, Haroon Shahzad b, M. Sajjad Saeed c, Sana Ullah d, M. Asif Ali a, Fakhar Mujeeb a, M.A. Anjum a}

\author{
a Agricultural Biotechnology Research Institute, AARI Faisalabad, Pakistan \\ ${ }^{b}$ Arid Zone Research Centre, PARC, D. I. Khan, Pakistan \\ c Pulses Research Institute, AARI, Faisalabad, Pakistan \\ d Institute of Soil \& Environmental Sciences, University of Agriculture Faisalabad, Pakistan
}

\section{Article Info}

Received : 02.10.2018

Accepted : 25.03.2019

\begin{abstract}
Legumes compensate mineral fertilizer by fixing nitrogen due to the specialized structures i.e. nodules by Rhizobium species. Literature revealed that legumes fixed nitrogen due to Rhizobium inoculation from 50-300 kg NPK ha-1 year-1. Rhizobium besides nitrogen fixation, solubilized phosphates, produced growth hormones and due to its root colonizing ability improved the growth and yield of non-legumes also and performed as plant growth promoting rhizobacteria (PGPR). Study was conducted to assess the relative efficiency of Rhizobium species for the growth and yield of cotton. Different isolates of five species of Rhizobium species responsible for different nodule formation in legumes were assessed for the auxin biosynthesis potential as IAA equivalents and isolates having higher values for IAA equivalents were used for experimentation. Results revealed that isolates of Rhizobium species improved the growth and physiological parameters of cotton. Higher values were root/shoot length and mass were observed with Rhizobium species of berseem $\left(\mathrm{Br}_{5}\right)$. Bacterial inoculation with isolate $\left(\mathrm{Br}_{5}\right)$ produced $60.94,64.40 \mathrm{~g}$ shoot/root mass that is 16.70 and $23.80 \%$ higher than control and percent increase improvements of cotton shoot/root length with $\mathrm{Br}_{5}$ i.e. 18.3, $24.8 \%$ higher than that of control. Higher values of IAA equivalents were observed in root/shoot content of cotton with isolate of $\mathrm{Br}_{5}$. Bacterial inoculation improved the plant height, boll weight, number of bolls plant ${ }^{-1}$ and seed cotton yield with $\mathrm{Br}_{5}$ inoculation. The chlorophyll content, photosynthetic rate, transpiration rate and photo active radiation were also higher in the inoculated treatments. Results of present study clearly demonstrated that different isolates of Rhizobium species improved the growth and yield parameters of cotton and thus Rhizobium sp can be effectively utilized as bacterial inoculants in non-legumes.
\end{abstract}

Keywords: Rhizobium species, PGPR, auxin biosynthesis, growth and yield, cotton.

(C) 2019 Federation of Eurasian Soil Science Societies. All rights reserved

\section{Introduction}

Cotton is the major cash crop of the country. It requires balanced amount of nutrients for proper growth and development. Microbial inoculants have the potential to compensate the mineral fertilizer and to provide a balanced diet to cotton. Biofertilizer technology has taken a part to minimize production costs and at the same time, avoid the environmental hazards (Galal et al., 2001).

The microbe responsible for formulations of nodules i.e. mini factories of nitrogen is Rhizobium. Different species of Rhizobium forms nodules on different legumes. More than 20,000 members of family Fabaceae form nodules with Rhizobium (Gepts et al., 2005). Specificity of Rhizobium species is due to the chemical

\footnotetext{
${ }^{*}$ Corresponding author.

Agricultural Biotechnology Research Institute, AARI Faisalabad, Pakistan

Tel.: +92 419201807

e-ISSN: 2147-4249
}

E-mail address: qureshifsd@gmail.com DOI: $10.18393 /$ ejss.544747 
signaling between host legume and Rhizobium sp. Rhizobium-legume symbiosis is a well distinguished feature of legumes. Legumes fulfill most of its nitrogen by these symbiotic relationships. Rhizobium inoculation has been carried out in our agricultural systems for more than a century. Rhizobium besides nitrogen fixation in legumes also involved in variety of functions like P-solubilization due to production of organic acids, growth hormone production like auxins, gibberellins etc. and antibiotics (Sessitsch et al., 2002; Cassán et al., 2009; Mehboob et al., 2009; Ullah et al., 2017a). Literature reported that rhizobium strains influenced the roots of cotton due to the production of auxins resulted in efficient nutrient uptake (Hafeez et al., 2004; Hossain and Mårtensson, 2008; Gopalakrishnan et al., 2015).

Interactions between plants and microorganisms in the rhizosphere can clearly affect crop yields. Rhizobacteria that benefit plant growth and development are called PGPR. PGPR can directly stimulate plant growth by producing phytohormones and by increasing nutrient uptake (Lippmann et al., 1995; Egamberdieva et al., 2008; Cassán et al., 2009) or by inducing systemic plant resistance towards pathogenic micro-organisms (Mehboob et al., 2009; Noreen et al., 2012; Kumar and Jagadeesh, 2016). PGPR can stimulate plant growth indirectly by inhibiting the root pathogens (Gopalakrishnan et al., 2015; Habig et al., 2015). Rhizobia as a PGPR should be able to colonize and survive in the rhizosphere of non-legume plants because root colonization is an important first step in the interaction of beneficial bacteria with plants (Kloepper and Beauchamp, 1992; Mehboob et al., 2009; Egamberdieva, 2011; Habig et al., 2015; Kumar and Jagadeesh, 2016; Ullah et al., 2017a). Root colonization is the most crucial step for successful use of PGPR (Lugtenberg et al., 2001). PGPR facilitated the plants to uptake nutrients present in soil environment (Glick, 1995; Mehboob et al., 2009; Habig et al., 2015). Microbial inoculants only exhibited marginal increase in yield when tested under ideal conditions due to inconsistent response of crops (Mehboob et al., 2009). Researchers reported that crops inoculated with rhizobia exhibited increased amount of nutrients than uninoculated control (Biswas et al., 2000; Egamberdieva, 2011). Rhizobia having the potential of Psolubilization also enhance plant growth by increasing the nutrient mobilization, enhancing the availability of other trace elements and by production of plant growth promoting substances (Gyaneshwar et al., 1998; Gepts et al., 2005; Mehboob et al., 2009; Egamberdieva, 2011; Kumar and Jagadeesh, 2016). Present study was conducted to assess the comparative potential of Rhizobium species (berseem, chickpea, lentil, vegetable pea and mung bean) on growth and yield of cotton.

\section{Material and Methods}

\section{Isolation and purification of rhizobia of different crops}

Yeast Extract Mannitol Agar (YMA) medium is used for the isolation of the Rhizobium spp. having composition per liter $\left(5 \% \mathrm{~K}_{2} \mathrm{HPO}_{4}: 10 \mathrm{ml} ; 2 \% \mathrm{MgSO}_{4} \cdot 7 \mathrm{H}_{2} \mathrm{O}: 10 \mathrm{ml} ; 1 \% \mathrm{NaCl}\right.$ : $10 \mathrm{ml}$; mannitol: 10 g; yeast extract: $1 \mathrm{~g}$; agar: $15.0 \mathrm{~g}$ ) (Vincent, 1970). For the preparation of the medium, the salts specified above were weighed and dissolved in water in pan and heated to dissolve the contents then it is shifted to conical flask and sterilized by autoclaving for $15-30$ minutes at $15-20 \mathrm{lb} \mathrm{inch}^{-2}$ pressure and $121^{\circ} \mathrm{C}$. After sterilization the media was poured on Petri plates aseptically in a laminar air flowcabinet and allow to solidify. Then this media is further surface sterilized by putting these plates in laminar flow cabinet under UV light.

Plants of berseem, chickpea, lentil, vegetable pea and mung bean are uprooted at nodulation stage. The roots are thoroughly washed with tap water to remove soil particles from roots. Now collect the healthy nodules from roots of each crop plant without damaging the nodule. Now these undamaged nodules are immersed in 95\% ethanol for 4-5 minutes. Then rinse them with sterilized distilled water. Now nodules are surface sterilized with $0.1 \% \mathrm{HgCl}_{2}$ followed by washing with sterilized distilled water. Now punctured the nodule with needle or crushed it with sterilized forceps. Immediately streak the juice of punctured nodule on solidified YMA media in Petri plates in air flow cabinet by surface sterilized streaking needle. Incubate the inoculated media for 48-72 hours. The prolific colonies can be seen on the plate media after 2 days as they don't attained congored color. These colonies are then further multiplied on fresh prepared Petri plates as well as purified in slants and kept at $5 \pm 1^{\circ} \mathrm{C}$ for further experimentation.

\section{Determination of auxin biosynthesis status of these Rhizobia spp.}

Isolates of Rhizobium sp berseem $\left(\mathrm{Br}_{1}, \mathrm{Br}_{2}, \mathrm{Br}_{3}, \mathrm{Br}_{4}, \mathrm{Br} 5\right)$, chickpea $\left(\mathrm{CP}_{1}, \mathrm{CP}_{2}, \mathrm{CP}_{3}, \mathrm{CP}_{4}, \mathrm{CP}_{5}\right)$, lentil $\left(\mathrm{L}_{1}, \mathrm{~L}_{2}, \mathrm{~L}_{3}, \mathrm{~L}_{4}\right.$, $\left.L_{5}\right)$ mung $\left(M_{1}, M_{2}, M_{3}, M_{4}, M_{5}\right)$ and Vegetablepea $\left(V p_{1}, V p_{2}, V_{3}\right)$ werescreened for their auxin biosynthesis potential colorometrically. For this purpose the isolates were cultured on the autoclavedGPM broth in test tubes with and without L-Tryptophan. The test tubes were covered and incubated at $28 \pm 2^{\circ} \mathrm{C}$ for one week and well shaken regularly throughout the week. The Un- inoculated control was kept for comparison. After incubation the contents were centrifuged @1000 rpm for 10 minutes and filtered through whatman filter paper No.2. The auxin biosynthesis potential was determined as Indole-3-acetic acid (IAA) equivalents by 
spectrophotometer at $535 \mathrm{~nm}$ using Salkowski's reagent $\left(2 \mathrm{~mL}\right.$ of $0.5 \mathrm{M} \mathrm{FeCl}_{3}+98 \mathrm{~mL}$ of $35 \% \mathrm{HClO}_{4}$ ) as reported by Sarwar et al. (1992). Isolates exhibited the highest auxin biosynthesis $\left(\mathrm{Br}_{5}, \mathrm{Cp}_{5}, \mathrm{~L}_{3}, \mathrm{Vp}_{2}\right.$ and $\left.\mathrm{M}_{3}\right)$ were selected for the study as mentioned in the Table 1.

Table 1. Some different traits of microbes under study

\begin{tabular}{|c|c|c|c|c|c|c|}
\hline \multirow[b]{2}{*}{ Rhizobium spp. } & \multirow[b]{2}{*}{ Isolates } & \multicolumn{2}{|c|}{ IAA equivalents ( $\left.\mu \mathrm{g} \mathrm{mL}^{-1}\right)$} & \multirow[b]{2}{*}{ Congo-red test } & \multirow{2}{*}{$\begin{array}{c}\text { Bromo-thymol } \\
\text { Blue test }\end{array}$} & \multirow[b]{2}{*}{ Gram Reaction } \\
\hline & & L-TRP [-] & L-TRP [+] & & & \\
\hline \multirow{5}{*}{ Berseem } & $\mathrm{Br}_{1}$ & 3.91 & 4.98 & + & + & - \\
\hline & $\mathrm{Br}_{2}$ & 4.33 & 5.37 & + & - & - \\
\hline & $\mathrm{Br}_{3}$ & 3.77 & 5.26 & + & + & - \\
\hline & $\mathrm{Br}_{4}$ & 4.12 & 5.68 & + & + & - \\
\hline & $\mathrm{Br}_{5}$ & 4.48 & 6.54 & + & + & - \\
\hline \multirow{5}{*}{ Chickpea } & $\mathrm{Cp}_{1}$ & 3.05 & 4.40 & + & + & - \\
\hline & $\mathrm{Cp}_{2}$ & 4.15 & 5.23 & + & + & - \\
\hline & $\mathrm{Cp}_{3}$ & 3.38 & 4.37 & + & + & - \\
\hline & $\mathrm{Cp}_{4}$ & 3.97 & 5.12 & + & - & - \\
\hline & $\mathrm{Cp}_{5}$ & 3.81 & 5.95 & + & + & - \\
\hline \multirow{5}{*}{ Lentil } & $\mathrm{L}_{1}$ & 4.05 & 5.10 & + & - & - \\
\hline & $\mathrm{L}_{2}$ & 4.39 & 5.28 & + & - & - \\
\hline & $\mathrm{L}_{3}$ & 4.47 & 5.39 & + & + & - \\
\hline & $\mathrm{L}_{4}$ & 3.55 & 4.20 & + & + & - \\
\hline & $\mathrm{L}_{5}$ & 3.33 & 4.51 & + & - & - \\
\hline \multirow{3}{*}{ Vegetable Pea } & $\mathrm{Vp}_{1}$ & 3.22 & 4.25 & + & + & - \\
\hline & $\mathrm{Vp}_{2}$ & 3.67 & 4.76 & + & + & - \\
\hline & $\mathrm{Vp}_{3}$ & 3.12 & 4.19 & + & + & - \\
\hline \multirow{5}{*}{ Mung bean } & $\mathrm{M}_{1}$ & 3.96 & 4.02 & + & - & - \\
\hline & $\mathrm{M}_{2}$ & 3.71 & 4.11 & + & + & - \\
\hline & $\mathrm{M}_{3}$ & 4.24 & 4.91 & + & + & - \\
\hline & $\mathrm{M}_{4}$ & 3.95 & 4.64 & + & - & - \\
\hline & $\mathrm{M}_{5}$ & 3.77 & 4.98 & + & + & - \\
\hline
\end{tabular}

\section{Preparation of inoculum}

Now YMB broth with composition per liter (Mannite: 10g; Yeast extract: 1g; $\mathrm{K}_{2} \mathrm{HPO}_{4} \quad(5 \%): 10 \mathrm{~mL}$; $\mathrm{MgSO}_{4} .7 \mathrm{H}_{2} \mathrm{O}(2 \%): 10 \mathrm{~mL} ; \mathrm{NaCl}(1 \%): 10 \mathrm{~mL}$ ) is prepared and autoclaved at $121^{\circ} \mathrm{C}$ temperature and $15-20 \mathrm{lb} /$ inch ${ }^{2}$ pressure. This autoclaved broth is then inoculated with purified and high biosynthetically auxins producing colonies of Rhizobium sp $\left(\mathrm{CP}_{5}, \mathrm{Br}_{2}, \mathrm{~L}_{4}, \mathrm{M}_{2}\right.$ and $\left.\mathrm{Vp}_{2}\right)$ in laminar flow and incubated at $25^{\circ} \mathrm{C}$ for 48 hours. When we see the maximum growth of rhizobium in broth then the seeds of Cotton are soaked in the prepared inoculum.

\section{Pot experiment}

A pot study was conducted in medium textured soil having pH 7.88, EC $1.47 \mathrm{dSm}^{-1}, \mathrm{~N} 0.043 \%$ and available $\mathrm{P}$ $7.35 \mathrm{mg} \mathrm{kg}^{-1}$ at Soil Bacteriology Section, AARI, Faisalabad. Experiment comprised of the following treatments included Control, Rhizobium sp (Berseem), Rhizobium sp (Chickpea), Rhizobium sp (Lentil), Rhizobium sp (Mungbean), Rhizobium sp (Vegetablepea). Fertilizer @ 100-60 kg NP ha-1 was applied to all treatments. Experiment was laid out in completely randomized design (CRD) with five replications. All phosphorus andhalf nitrogen were applied as basal and half nitrogen was applied after 30 days of sowing. The photosynthetic rate, transpiration rate and photoactive radiation were determined by using IRGA (CI340). Two repeats of cotton were uprooted after 45 days by irrigating the pots to record root / shoot length and mass. Then after 30 minutes when the soil became soft water from pipe was poured on to the pot as soil is removed and plant of cotton along with roots without any damage are obtained. The remaining three repeats were kept until maturity and growth / yield parameters were recorded. Data were subjected to statistical analysis by analysis of variance following completely randomized design (CRD) (Steel et al., 1997) and differences among the means were compared by the Duncan's multiple range test (Duncan, 1955).

\section{Lab analysis}

Chlorophyll content of leaf of each replication is determined colorimetrically by crushing the leaves in acetone and by centrifuging @ 1000 rpm for 10 minutes then run on spectrophotometer (Arnon, 1949). After uprooting the plants physical parameters like root and shoot length is measured by measuring scale in centimeters while root and shoot mass is determined by using digital balance. Then two gram of each of the root and shoot of each repeat is taken that is dipped and ground in autoclaved 10mL GPM in test tube and 
covered with cork. Two GPM containing test tubes are kept as control. This is kept for one week and shaken well three times a day regularly. Then the contents are centrifuged @ 1000 rpm for 20 minutes. 5 standards of auxin (1, 2, 3, 4 and 5) ppm were made from $1000 \mathrm{ppm}$ auxin stock solution. Three $\mathrm{mL}$ of supernatant and auxin standards are taken in test tubes and added $2 \mathrm{~mL}$ of Salkowski's reagent $\left(98 \mathrm{~mL} 35 \% \mathrm{HClO}_{4}+2 \mathrm{~mL} 0.5 \mathrm{M}\right.$ $\mathrm{FeCl}_{3}$ ) to each tube. After 30 minutes a pink color ring is formed on top of GPM supernatant that indicated presence of auxin. The samples were run these samples on spectrophotometer @535nm spectrum and check the biosynthesis of auxin as IAA equivalents by plant shoot and root by comparing it with control.

\section{Results and Discussion}

Data regarding IAA production by different strain of Rhizobium isolated from root nodules of crops under study is presented in Table 1. Keeping in view the above data it can be observed that Rhizobium species isolated from nodules of berseem, chickpea, lentil, vegetable pea, mungbean $\left(\mathrm{Br}_{5}, \mathrm{Cp}_{5}, \mathrm{~L}_{3}, \mathrm{Vp}_{2}\right.$ and $\left.\mathrm{M}_{3}\right)$ produced higher auxin values in order of 4.48, 3.81, 4.47, 3.67 and $4.24 \mu \mathrm{g} \mathrm{ml}^{-1}$ and the values were more enhanced with the supplement of L-tryptophan i.e. 6.54, 5.95, 5.39, 4.76 and 4.91, respectively. It was observed that all tested isolates produced IAA equivalents and effect was more pronounced with the application of L-tryptophan. The biochemical tests such as Congo red test, bromothymol and gram reaction showed the characteristic features of the tested isolates.

Use of beneficial rhizobacteria to attain sustainable agriculture and nutrient availability for crop plants has been becoming an emerging approach in conservation of agriculture (Habig et al., 2015). Moreover, Rhizobia are potential partner of legumes crops but also act as beneficial rhizobacteria for non-legume or cereals (rice, maize, wheat) without forming nodules through different plant growth mechanisms such as nutrient availability, release of growth hormone, production of siderophores and lumichrome, improved root morphology, more root adhering soil and defense action (biocontrol, induced systemic resistance) (Mehboob et al., 2009; Kumar and Jagadeesh, 2016). Among the phytohormones (auxins, gibberellins, abscisic acid, ethylene), auxins play major role in plant-microbe interaction, and growth and development of plants (Boivin et al., 2016). In this experiment rhizobial species isolated from five different legumes were assayed for their IAA-producing efficiency then verified to affect the growth and yield attributes of cotton. In results, rhizobial isolates $\mathrm{Br}_{5}$ showed maximum IAA-potential hence better impact on cotton growth and yield than other isolates. Our observation regarding auxin production related to different studies which were conducted to investigate the potential of IAA-producing rhizobial species to enhance plant growth (Hussain et al., 2014; Parthiban et al., 2016).

Data regarding shoot/root mass is presented in Figure 1 showed that isolates of rhizobium species enhanced the shoot/root mass considerably. Inoculation with isolate $\mathrm{Br}_{5}$ produced $60.94,64.40 \mathrm{~g}$ shoot/root mass that is 16.70 and $23.80 \%$ higher than control while other isolates showed percent increase compared to control viz. $\mathrm{Cp}_{5}(8.1,20.3 \%), \mathrm{L}_{3}(8,18.0 \%), \mathrm{Vp}_{2}(4.3,12.6 \%), \mathrm{M}_{3}(4.7,9.4 \%)$, respectively.

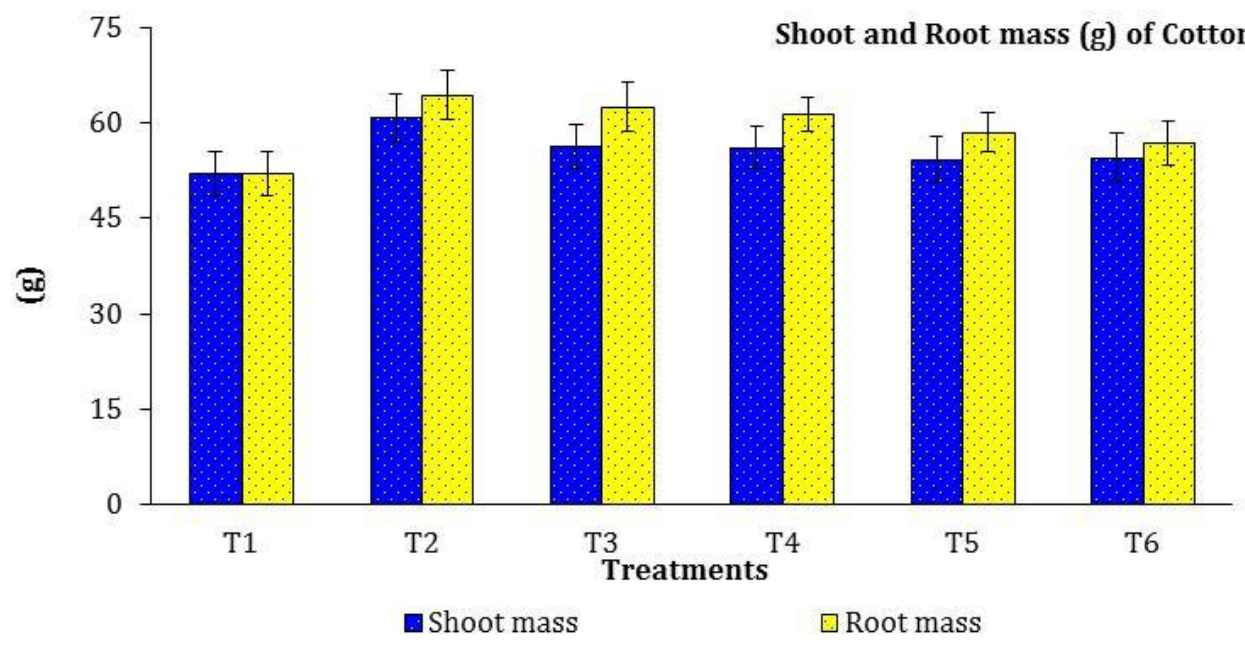

Figure 1. Comparative effect of rhizobium sp on shoot / root mass of cotton

Data regarding shoot / root length is presented in Figure 2 that showed that all isolates have improved the shoot/root length. Rhizibium isolates of $\mathrm{Br}_{5}, \mathrm{Cp}_{5}, \mathrm{~L}_{3}, \mathrm{Vp}_{2}$ and $\mathrm{M}_{3}$ improved the shoot/root length of cotton seedlings i.e. $(27.8,49.3 \mathrm{~cm}),(25.8,46.0 \mathrm{~cm}),(27.0,44.5 \mathrm{~cm}),(23.5,47 \mathrm{~cm})$ and $(24.8,48.0 \mathrm{~cm})$ as compared to control $(23.5,39.5 \mathrm{~cm})$, respectively. The percent increase improvements of cotton shoot/root length with 
$\mathrm{Br}_{5}$ i.e.18.3, $24.8 \%$ higher than that of control while $\mathrm{Cp}_{5}(9.8,16.5 \%), \mathrm{L}_{3}(14.9,12.7 \%)$ and $\mathrm{M}_{3}(5.53,21.5 \%)$ and isolate of $\mathrm{Vp}_{2}$ has no impact regarding shoot length of cotton while improved root length $19 \%$.

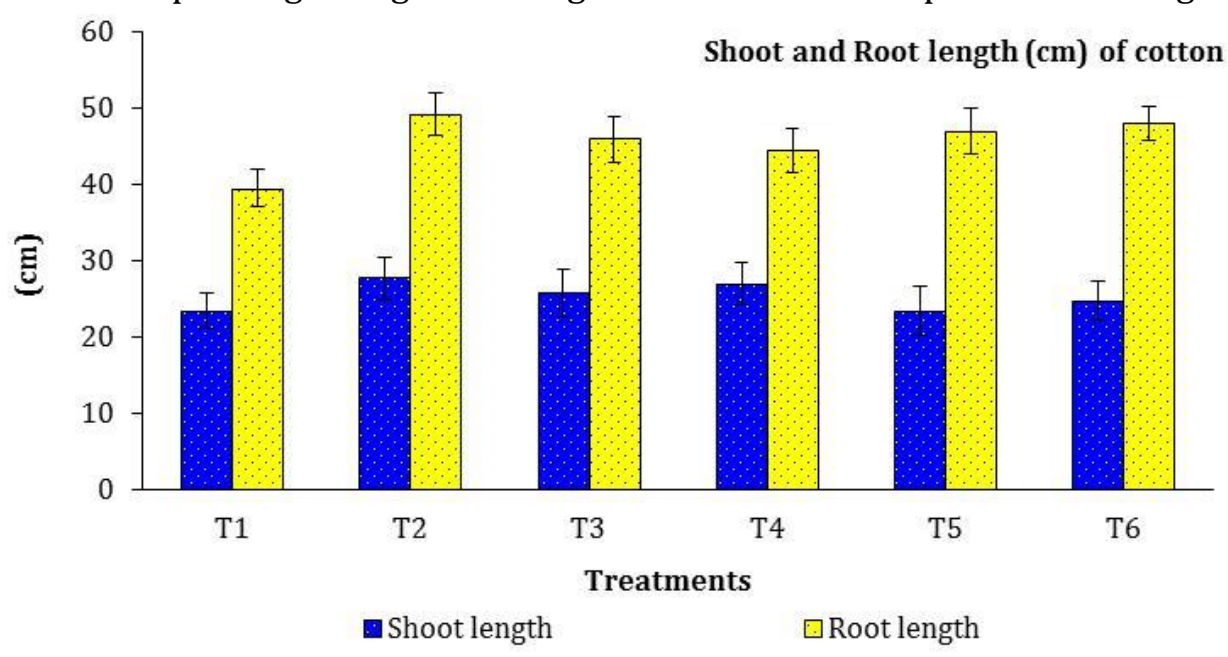

Figure 2. Comparative effect of rhizobium sp on shoot / root length of cotton

The IAA equivalents in shoot/root content of cotton seedlings are presented in Figure 3. Results clearly demonstrated that bacterial inoculation improved the IAA content in shoot/root content of cotton seedlings as compared to control and isolates showed variable response regarding shoot/root IAA content. Results showed that the highest value of shoot/root IAA content was obtained with Br5 i.e. 4.41 and $3.65 \mu \mathrm{g} \mathrm{g}^{-1}$ followed by $\mathrm{Cp}_{5}$ i.e. 4.41 and 3.49 as compared to control i.e. 2.35 and 1.95, respectively.

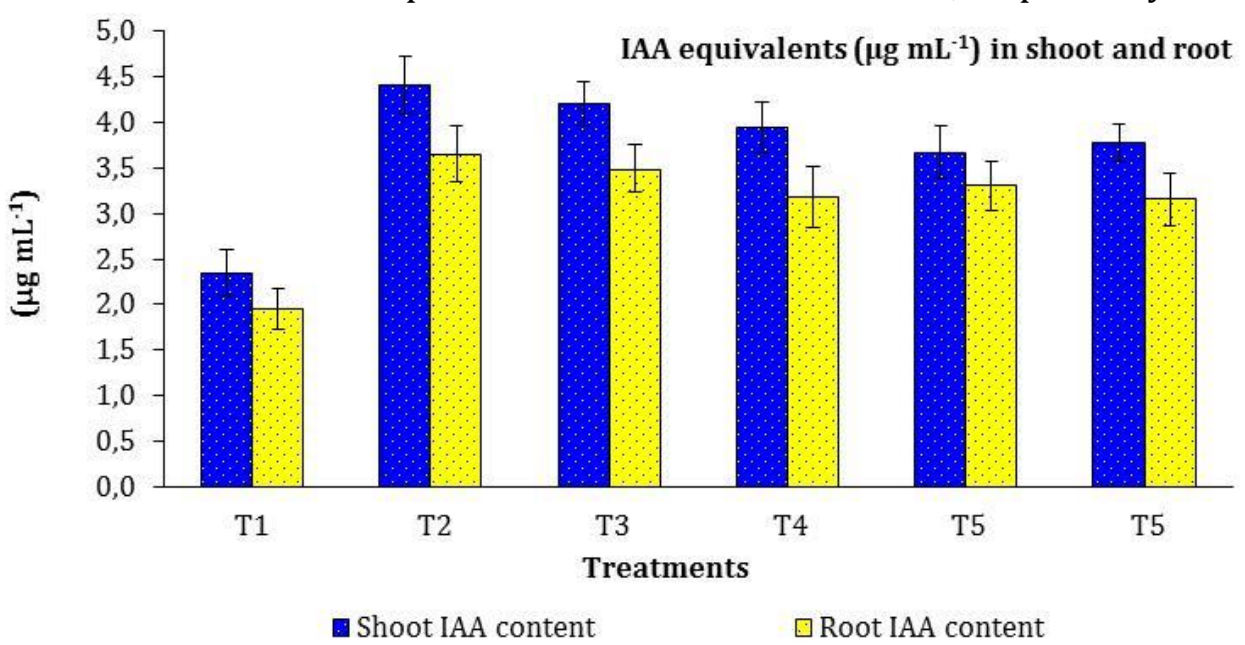

Figure 3. IAA equivalents in shoot / root content of cotton

Inoculation of cotton seeds with rhizobial isolate caused maximum increase in length and mass of root and shoot which might be due to production of lumichromes that help in $\mathrm{CO}_{2}$ assimilation by roots (Dakora, 2003), riboflavin which stimulate root respiration (Dakora et al., 2002) and auxins to promote cell elongation through their expansion action (Pacheco-Villalobos et al., 2016). Beneficial rhizobacteria also influence the cell division and differentiation of plant roots which caused improved growth of shoot system (Verbon et al., 2016). These improvements are in lined with the study of (Noreen et al., 2012) who observed 54, 45 and 185\% increase in root, shoot length and seedling fresh weight of Vignamungo (L.) when inoculated with IAA-generating strain Pseudomonas aeruginosa As-17. (Asghar et al., 2015) also noted a significant improvement in weight and length of root and shoots of wheat plants due to inoculation with different rhizobial isolates.

Data regarding physical parameters i.e. plant height, boll weight, boll plant ${ }^{-1}$, cotton leaf curl virus percentage (CLCV) and seed cotton yield from remaining repeats is presented in Table 2. Results regarding physical parameters demonstrated the positive response of Rhizobium species $\left(\mathrm{Br}_{5}, \mathrm{Cp}_{5}, \mathrm{~L}_{3}, \mathrm{Vp}_{2}\right.$ and $\left.\mathrm{M}_{3}\right)$. The maximum plant height i.e. 79.5 with $\mathrm{Br}_{5}$ followed by $\mathrm{Cp}_{5}$ i.e. $76.0 \mathrm{~cm}$ compared to control i.e. $72.0 \mathrm{~cm}$. The maximum boll weight was obtained with $\mathrm{Br}_{5}$ i.e. $2.87 \mathrm{~g}$ followed by $2.79 \mathrm{~g}$ with $\mathrm{Cp}_{5}$ inoculation compared to control i.e. 2.65 g. The maximum number of bolls was obtained with the isolate $\mathrm{Br}_{5}$ i.e. 15 followed by $\mathrm{Cp} 5$ i.e. 13.5 and the least number of bolls was obtained with M3 that is at par with control i.e. 10.5. Results 
regarding CLCV percentage, it was observed that the highest CLCV percentage was observed with control and the least was observed by inoculation with $\mathrm{Br}_{5}$. Results regarding seed cotton yield clearly demonstrated that bacterial inoculation improved the seed cotton yield (47.0 g) as compared to control (34.50), respectively. Increase in seed cotton yield due to bacterial inoculation $(36,27.5,18.8,12.3$, and 5.8\%) due to application of Rhizobium species i.e. $\mathrm{Br}_{5}, \mathrm{Cp}_{5}, \mathrm{~L}_{3}, \mathrm{Vp}_{2}$ and $\mathrm{M}_{3}$ was observed, respectively.

Table 2. Effect of bacterial inoculation on yield components of cotton and parameters recorded by the IRGA (CI-340).

\begin{tabular}{|c|c|c|c|c|c|c|c|c|c|}
\hline Treatments & $\begin{array}{l}\text { Plant } \\
\text { Height } \\
\text { (cm) }\end{array}$ & $\begin{array}{c}\text { Boll } \\
\text { weight } \\
\text { (g) }\end{array}$ & $\begin{array}{l}\text { Bolls } \\
\text { plant }^{-1}\end{array}$ & $\begin{array}{r}\text { CLCV } \\
(\%)\end{array}$ & $\begin{array}{c}\text { Seed } \\
\text { cotton } \\
\text { yield } \\
\left(\text { g pot }^{-1}\right) \\
\end{array}$ & $\begin{array}{c}\text { Photosynthetic } \\
\text { rate } \\
\left(\mu \text { mole } \mathrm{m}^{-2} \mathrm{~s}^{-1}\right)\end{array}$ & $\begin{array}{l}\text { Transpiration } \\
\text { rate } \\
\left(\text { mmole.m-2 } \mathrm{s}^{-1}\right)\end{array}$ & $\begin{array}{c}\text { Photo Active } \\
\text { Radiation } \\
\left(\mu \text { mole } \mathrm{m}^{-2} \mathrm{~s}^{-1}\right)\end{array}$ & $\begin{array}{c}\text { Total } \\
\text { Chlorophyll } \\
\text { content } \\
\left(\mathrm{mg} \mathrm{g}^{-1}\right) \\
\end{array}$ \\
\hline Control & $72.0^{* b c}$ & $2.65^{d}$ & $10.5^{b}$ & $36.0^{\mathrm{a}}$ & $34.50^{\mathrm{e}}$ & 78.0 & 7.80 & 841.0 & 1.35 \\
\hline $\begin{array}{l}\text { Rhizobium sp } \\
\text { (Berseem) }\end{array}$ & $79.5^{\mathrm{a}}$ & $2.87^{a}$ & $15.0^{\mathrm{a}}$ & $31.5^{\mathrm{b}}$ & $47.00^{\mathrm{a}}$ & 89.0 & 8.20 & 863.0 & 1.40 \\
\hline $\begin{array}{l}\text { Rhizobium sp } \\
\text { (Chickpea) }\end{array}$ & $76.0^{\mathrm{ab}}$ & $2.79^{b}$ & $13.5^{\mathrm{ab}}$ & $33.5^{\mathrm{ab}}$ & $44.00^{\mathrm{ab}}$ & 84.5 & 7.70 & 859.0 & 1.38 \\
\hline $\begin{array}{l}\text { Rhizobium sp } \\
\text { (Lentil) }\end{array}$ & $73.0^{\mathrm{bc}}$ & $2.76^{\mathrm{bc}}$ & $13.0^{\mathrm{ab}}$ & $35.0^{\mathrm{a}}$ & $41.00^{\mathrm{bc}}$ & 86.0 & 7.75 & 857.0 & 1.39 \\
\hline $\begin{array}{l}\text { Rhizobium sp } \\
\text { (Vegetable pea) }\end{array}$ & $73.0^{\mathrm{bc}}$ & $2.73^{\mathrm{bc}}$ & $12.0^{\mathrm{ab}}$ & $34.0^{\mathrm{ab}}$ & $38.75^{\mathrm{cd}}$ & 84.0 & 7.60 & 854.0 & 1.36 \\
\hline $\begin{array}{l}\text { Rhizobium sp } \\
\text { (Mung bean) }\end{array}$ & $69.0^{c}$ & $2.71^{\mathrm{cd}}$ & $10.5^{\mathrm{b}}$ & $34.5^{a}$ & $36.50^{\mathrm{de}}$ & 85.5 & 7.80 & 853.5 & 1.37 \\
\hline LSD & 5.142 & 0.0696 & 3.670 & 2.736 & 3.619 & 14.37 & 1.372 & 127.08 & 0.052 \\
\hline
\end{tabular}

*Means sharing the same letter(s) in a column do not differ significantly at $\mathrm{p}<0.05$ according to Duncan's Multiple Range Test

Rhizobial inoculum left potential impact on cotton plants and increased the biomass and yield parameters of cotton crop including number of bolls per plant, boll weight and seed cotton yield. It might be attributed to different rhizospheric-synergistic effects of rhizobia such as biocontrol against pathogens (Hossain and Mårtensson, 2008), cyanide production (Adnan et al., 2016), production of exopolysacharides, antioxidants, better colonization ability (Hussain et al., 2014), growth hormones (Qureshi et al., 2013) like IAA in the cotton rhizosphere which improved root morphology, root proliferation (Hussain et al., 2009) thus better root system for acquisition and uptake of mineral nutrients (N, P and K) as seen in case of rice seed and seedling inoculation with different Rhizobium spp (i.e. Bradyrhizobium sp IRBG271, $R$. leguminosarum bv. trifolii E11 and Rhizobium sp. IRBG74,) (Biswas et al., 2000) ultimately improving cotton yield. Our results relevant to a recent study conducted by (Arshad et al., 2016) who found a substantial increment (13\%) in lint and seed yield of transgenic and non-transgenic cotton plants upon inoculation with IAA-producing rhizobacterial strainBrevibacillus spp. TN4-3NF in comparison to un-inoculated control plants.

Results regarding different parameters obtained with IRGA (CI340) like Photosynthetic rate, Transpiration rate, Photo active radiation (PAR) and total chlorophyll content obtained by spectrophotometer are presented in Table 2. Results showed that the maximum photosynthetic, transpiration and PAR values were observed with Rhizobium sp (Brs) i.e. $89.0 \mu$ mole $\mathrm{m}^{-2} \mathrm{~s}^{-1}, 8.2 \mathrm{mmole} \mathrm{m}^{-2} \mathrm{~s}^{-1}$ and $863 \mu \mathrm{mole} \mathrm{m}^{-2} \mathrm{~s}^{-1}$ and total chlorophyll content $1.40 \mathrm{mg} \mathrm{g}^{-1}$, respectively.

Seed inoculation of cotton with rhizobial isolates put positive influence on physiology of cotton plants, thus, enhancing the photosynthetic activity and transpiration rate. This improvement by rhizobia may be due to the production of siderophoresenhancing iron (part of chlorophyll) supply, growth hormones (Adnan et al., 2016) and exopolysaccharide which facilitate water and mineral supply throughimproved root system (Egamberdieva and Kucharova, 2009; Hussain et al., 2014) ensuring better plant physiology for normal growth and development of cotton plants. These finding of our experiment according to an experiment in which inoculation of maize seeds with two PGPR strains (B.phytofirmans PsJN and Enterobactersp. FD17) caused significant increase in physiological parameters (photosynthetic rate 75\%, stomatal conductance $87 \%$, transpiration rate $84 \%$, chlorophyll contents $22 \%$ of plants (Naveed et al., 2014).

Study results concluded that Rhizobium species are effective PGPR if screened thoroughly and by determining its growth hormone production potential. Present study also predicted that Rhizobium species have specific response on different crops also study concluded that Rhizobium species having growth hormone production potential should have root colonizing ability for successful utilization in non-legumes. 


\section{References}

Adnan, M., Shah, Z., Saleem, N., Basir, A., Rahman, I., Ulah, H., Ibrahim, M., Shah, J.A., Muhammad, Khan, A., Shah, S.R.A., 2016. Isolation and evaluation of summer legumes Rhizobia as PGPR. Pure and Applied Biology 5(1): 127-133.

Arnon, D.I., 1949. Copper enzymes in isolated chloroplasts.polyphenoloxidase in Beta vulgaris. Plant Physiology 24(1): 1-15.

Arshad, M., Leveaue, J.H., Asad, S., Imran A., Mirza, M.S., 2016. Comparison of rhizospheric bacterial populations and growth promotion of avp1 transgenic and non-transgenic cotton by bacterial inoculations. Journal of Animal and Plant Sciences 26(5): 1284-1290.

Asghar, N., Zahir, Z.A., Akram, M.A., Ahmad, H.T., Hussain, M.B., 2015. Isolation and screening of beneficial bacteria to ameliorate drought stress in wheat. Soil and Environment 34(1): 100-110.

Biswas, C., Ladha, J.K., Dazzo, F.B., 2000. Rhizobia inoculation improves nutrient uptake and growth of lowland rice. Soil Science Society of America Journal 64(5): 1644-1650.

Boivin, S. Fonouni-Farde, C., Frugier, F., 2016. How auxin and cytokinin phytohormones modulate root microbe interactions. Frontiers in Plant Science 7, 1240.

Cassán, F., Maiale, S., Masciarelli, O., Vidal, A., Luna, V., Ruiz, O., 2009. Cadaverine production by Azospirillum brasilense and its possible role in plant growth promotion and osmotic stress mitigation. European Journal of Soil Biology 45(1): 12-19.

Dakora, F.D., 2003. Defining new roles for plant and rhizobial molecules in sole and mixed plant cultures involving symbiotic legumes. New Phytologist 158(1): 39-49.

Dakora, F.D., Matiru, V., King, M., Phillips, D.A., 2002.Plant growth promotion in legumes and cereals by lumichrome, a rhizobial signal metabolite. In: Nitrogen Fixation: Global Perspectives. Finan, T.M., O’Brian, M.R., Layzell, D.B., Vessey, K., Newton, W.E. (Eds.). CABI Publishing, Wallingford, U.K. pp.321-322.

Duncan, B., 1955. Multiple Range and Multiple F Test. Biometrics 11: 1-42.

Egamberdieva, D., 2011. Survival of Pseudomonas extremorientalis TSAU20 and P.chlororaphis TSAU13 in the rhizosphere of common bean (Phaseolus vulgaris) under saline conditions. Plant, Soil and Environment 57(3): 122-127.

Egamberdieva, D., Kucharova, Z., 2009. Selection for root colonizing bacteria stimulating wheat growth in saline soils. Biology and Fertility of Soils 45(6): 563-571.

Egamberdieva, D.F., Kamilova, F., Validov, S., Gafurova, L., Kucharova, Z., Lugtenberg B., 2008. High incidence of plant growth-stimulating bacteria associated with the rhizosphere of wheat grown on salinated soil in Uzbekistan. Environmental Microbiology 10(1): 1-9.

Galal, Y.G., El-Gandaour, J.A., El-Akel, F.A., 2001. Stimulation of wheat growth and N Fixation through Azospirillum and Rhizobium inoculation. A Field trial with $15 \mathrm{~N}$ techniques. Plant Nutrition. Developments in Plant and Soil Sciences. Horst, W.J., Schenk, M.K., Bürkert, A., Claassen, N., Flessa, H., Frommer, W. B., Goldbach, H., Olfs, H.W., Römheld, V., Sattelmacher, B., Schmidhalter, U., Schubert, S., Wirén, N., Wittenmayer, L. (Eds.). vol 92. Springer, Dordrecht. pp. 666-667.

Gepts, P., Beavis, W.D., Brummer, E.C., Shoemaker, R.C., Stalker, H.T., Weeden, N.F., Young, N.D., 2005. Legumes as a model plant family: Genomics for food and feed report of cross-legume advances through genomics conference. Plant Physiology 137: 1228-1235.

Glick, B.R., 1995. The enhancement of plant growth by free living bacteria. Canadian Journal of Microbiology 41(2): 109117.

Gopalakrishnan, S., Sathya, A., Vijayabharathi, R., Varshney, R.K., Gowda, C.L.L., Krishnamurthy, L., 2015. Plant growth promoting rhizobia: challenges and opportunities. Biotechnology 5(4): 355-377.

Gyaneshwar, P., Kumar, G.N., Parekh, L.J., 1998. Effect of buffering on the phosphate solubilizing ability of microorganisms. World Journal of Microbiology and Biotechnology 14(5): 669-673.

Habig, J., Hassen, A., Swart, A., 2015. Application of microbiology in conservation agriculture. In: Conservation Agriculture, Farooq, M., Siddique, K.H.M. (Eds.) Springer International Publishing, Switzerland. pp.525-557.

Hafeez, F.Y., Safdar, M.E., Chaudhry, A.U., Malik, K.A., 2004. Rhizobial inoculation improves seedling emergence, nutrient uptake and growth of cotton. Australian Journal of Experimental Agriculture 44(6): 617-622.

Hossain, Md.S. Mårtensson, A., 2008. Potential use of Rhizobium spp. to improve fitness of non-nitrogen-fixing plants. Acta Agriculturae Scandinavica, Section B - Soil \& Plant Science 58(4): 352-358.

Hussain, M.B., Mehboob, I., Zahir, Z.A., Naveed, M., Asghar, H.N., 2009. Potential of Rhizobium spp. for improving growth and yield of rice (Oryza sativa L.). Soil and Environment 28(1): 49-55.

Hussain, M.B., Zahir, Z.A., Asghar, H.N., Asgher, N., 2014. Can catalase and exopolysaccharides producing rhizobia ameliorate drought stress in wheat?. International Journal of Agriculture and Biology 16(1): 3-13.

Kloepper, J.W., Beauchamp, C.J., 1992. A review of issues related to measuring colonization of plant roots by bacteria. Canadian Journal of Microbiology 38(12): 1219-1232.

Kumar, H., Jagadeesh, K.S., 2016. Microbial consortia-mediated plant defense against phytopathogens and growth benefits. South Indian Journal of Biological Sciences 2(4): 395-403.

Lippmann, B., Leinhos, V., Bergmann, H., 1995. Influence of auxin producing rhizobacteria on root morphology and nutrient accumulation of crops. I. Changes in root morphology and nutrient accumulation in maize (Zea mays L.) 
caused by inoculation with indole-3-acetic acid (IAA) producing Pseudomonas and Acinetobacter strains or IAA applied exogenously. Angewandte Botanik 69(1-2): 31-36

Lugtenberg, K.J.J., Dekkers, L., Bloemberg, J.V., 2001. Molecular determinants of rhizosphere colonization by Pseudomonas. Annual Review of Phytopathology 39: 461-490.

Mehboob, I., Naveed, M., Zahir, Z.A., 2009. Rhizobial association with non-legumes: mechanisms and applications. Critical Reviews in Plant Sciences 28(6): 432-456.

Naveed, M., Mitter, B., Reichenauer, T.G., Wieczorek, K., Sessitsch, A., 2014. Increased drought stress resilience of maize through endophytic colonization by Burkholderia phytofirmans PsJN and Enterobacter sp. FD17. Environmental and Experimental Botany 97: 30-39.

Noreen, S., Ali, B., Hasnain, S., 2012. Growth promotion of Vigna mungo (L.) by Pseudomonas spp. exhibiting auxin production and ACC-deaminase activity. Annals of Microbiology 62(1): 411-417.

Pacheco-Villalobos, D., Diaz-Moreno, S.M., Schuren, A.V.D., Tamaki, T., Kang, Y.H., Gujas, B., Novak, O., Jaspert, N., Li, Z., Wolf, S., Oecking, C., Ljung, K., Bulone, V., Hardtke, C.S., 2016. The effects of high steady state auxin levels on root cell elongation in Brachypodium. The Plant Cell 28: 1009-1024.

Parthiban P., Shijila Rani A.S., Mahesh V., Ambikapathy V., 2016. Studies on biosynthesis of auxin in rhizobium and their impact on growth of Vigna mungo L. Pharmaceutical and Biological Evaluations 3(3): 371-376.

Qureshi, A., Shahzad, H., Imran, Z., Mushtaq, M., Akhtar, N., Ali, M.A., Mujeeb, F., 2013. Potential of Rhizobium species to enhance growth and fodder yield of maize in the presence and absence of L-tryptophan. Journal of Animal and Plant Sciences 23(5): 1448-1454.

Sarwar, M., Martens, D.A., Arshad, M., Frankenberger Jr., W.T., 1992. Tryptophan-dependent biosynthesis of auxins in soil. Plant and Soil 147(2): 207-215.

Sessitsch, A., Howieson, J.G., Perret, X., Antoun, H., Martínez-Romero, E., 2002. Advances in Rhizobium research. Critical Reviews in Plant Sciences 21(4): 323-387.

Steel, R.G.D., Torrie, J.H., Dickey, D.A., 1997. Principles and Procedures of Statistics: A Biometrical Approach. $3^{\text {rd }}$ Ed. McGraw-Hill Book International Co., Singapore. 666p.

Ullah, S., Qureshi, M.A., Ali, M.A., Mujeeb, F., Yasin, S., 2017a.Comparative potential of Rhizobium species for the growth promotion of sunflower (Helianthus annuus L.). Eurasian Journal of Soil Science 6(3): 189-196.

Ullah, S., Khan, M.Y., Asghar, H.N., Akhtar, M.J., Zahir, Z.A., 2017b. Differential response of single and co-inoculation of Rhizobium leguminosarum and Mesorhizobiumciceri for inducing water deficit stress tolerance in wheat. Annals of Microbiology 67(11): 739-749.

Verbon, E.H., Liberman, L.M., 2016. Beneficial microbes affect endogenous mechanisms controlling root development. Trends in Plant Science 21(3): 218-229.

Vincent, J.M., 1970. A manual of practical study of root nodule bacteria. IBP Handbook No. 15. Blackwell Scientific Publications Oxford and Edinburgh, UK, 